\title{
ANALISIS PENGARUH LABA AKUNTANSI DAN ARUS KAS OPERASI TERHADAP RETURN SAHAM (Studi Pada Perusahaan Manufaktur Sektor Aneka Industri Yang Terdaftar Di Bursa Efek Indonesia Periode 2013-2017)
}

\author{
Christina \\ dan \\ Wasis Rokhanah
}

\author{
Fakultas Ekonomi Program Studi Akuntansi \\ Universitas Satya Negara Indonesia
}

\begin{abstract}
ABSTRAK
Laba dapat menjadi pengukuran atas efisiensi serta dapat menjadi pengukur keberhasilan dan sebagai pedoman pengambilan keputusan manajemen dimasa yang akan datang. Penilaian atas laba juga merupakan tingkat pengembalian investasi (return), semakin besar laba yang diperoleh perusahaan, maka semakin baik dimata investor pada pasar modal. Bagian lain yang sering digunakan investor adalah informasi arus kas perusahaan. Penelitian ini bertujuan untuk mengetahui pengaruh antara laba akuntansi dan arus kas operasi terhadap return saham.

Penelitian ini menggunakan sampel perusahaan manufaktur sektor aneka industri yang terdaftar di Bursa Efek Indonesia periode tahun 2013-2017. Teknik yang digunakan dalam pengambilan sampel pada penelitian ini dengan menggunakan teknik purposive sampling, dan diperoleh sampel berjumlah 11 perusahaan. Metode analisis dalam penelitian ini menggunakan analisis regresi linear berganda, dengan menggunakan perangkat lunak pemrosesan data statistik SPSS 24.00 for windows.

Hasil dari penelitian ini menunjukkan bahwa laba akuntansi dan arus kas operasi mempunyai pengaruh signifikan terhadap return saham baik secara parsial maupun simultan. Hasil mengindikasikan bahwa laba akuntansi dan arus kas operasi mempunyai dampak pada pasar saham terutama berpengaruh untuk return (pengembalian) dari dana yang diinvestasikan pada perusahaan manufaktur sektor aneka industri.
\end{abstract}

Kata kunci : laba akuntansi, arus kas operasi, return saham

\begin{abstract}
Financial statement information, especially related to accounting earnings and operating cash flow is an important information that can be used by users of financial statements, especially investors to know and assess the performance of a company. In the business mechanism, every owner, manager, and investor desperately need information relating to the performance of the company to measure the achievement of a company so it can be known the development of operational conditions of the company. The purpose of the financial statements is to provide information on the financial position, financial performance, and cash flows of entities beneficial to most users of the report in economic decision making (Financial Accounting Standards no. 1 of 2009).

This study aims to determine the effect of accounting earnings and operating cash flows on stock returns. This study uses a sample of manufacturing companies of various industry sectors listed in Indonesia Stock Exchange period 2013-2017. The technique used in sampling in this study by using purposive sampling technique, and obtained a sample of 11 companies. The method of analysis in this study using multiple linear regression analysis, using statistical data processing software SPSS 24.00 for windows.

The results of this study indicate that accounting earnings and cash flow operations have a significant influence on stock return either partially or simultaneously. The results indicate that accounting earnings and operating cash flows have an impact on the stock market in particular affecting the returns of funds invested in various industrial manufacturing sectors.
\end{abstract}

Keywords: accounting profit, operating cash flow, stock return 


\section{PENDAHULUAN}

Kemajuan pasar modal di Indonesia saat ini telah berkembang pesat serta berperan penting dalam memobilitasi dana investor yang akan berinvestasi. Ketika pasar modal menunjukkan suatu peningkatan maka dapat diartikan bahwa perekonomian suatu negara sedang dalam perkembangan, sedangkan jika sebaliknya apabila pasar modal sedang lesu maka dapat diartikan bahwa perekonomian suatu negara sedang mengalami penurunan. Indikator perkembangan tersebut dapat dilihat dari jumlah perusahaan yang terdaftar di Bursa Efek Indonesia (BEI) yang telah menunjukkan peningkatan, dimana saat ini hampir mencapai 568 perusahaan.

Fungsi penting dari pasar modal adalah sebagai sarana untuk memobilisasi dana yang bersumber dari masyarakat ke berbagai sektor yang melaksanakan investasi. Hal ini dikarenakan pasar modal sebagai media yang sangat efektif untuk dapat menyalurkan dan menginvestasikan dana yang berdampak produktif dan menguntungkan bagi investor. Selain itu, indikator utama yang diinginkan investor untuk bersedia menyalurkan dananya melalui pasar modal adalah perasaan aman akan investasinya. Sejalan dengan berkembangnya pasar modal di indonesia tentunya banyak investor atau perusahaan-perusahaan yang menginginkan informasi untuk mendapatkan sumber dana. Pengambilan keputusan keuangan untuk kegiatan investasi, akan sangat dipengaruhi oleh informasi yang didapat dan pengetahuan investor tentang investasi. Biasanya seorang investor akan melakukan riset sebelum memutuskan untuk melakukan investasi, seperti dengan mempelajari laporan keuangan perusahaan, kinerja perusahaan, track record atau portofolio, keadaan perekonomian, risiko, ulasan tentang keuangan dan keadaan perekonomian yang dipublikasikan di media dan lain-lain.

Salah satu cara investor untuk mendapatkan keuntungan atau memperluas bisnisnya adalah dengan aktivitas investasi saham. Investasi saham adalah bentuk investasi yang diminati di pasar modal karena ada dua keuntungan yaitu berupa dividen dan capital gain. Adanya informasi yang terpercaya dan relevan mengenai dinamika stock price di pasar modal sangat diperlukan bagi investor untuk dapat memperoleh keuntungan yang maksimum atas investasi saham yang dilakukan (Putra, 2014). Harga saham menunjukkan nilai perusahaan, semakin tinggi harga saham bisa diartikan bahwa semakin tinggi pula nilai perusahaan tersebut, begitupun sebaliknya.

Dalam mekanisme usaha, setiap pemilik, manajer, dan penanam modal sangat membutuhkan informasi yang berkaitan dengan kinerja perusahaan. Kinerja merupakan alat untuk mengukur prestasi kerja suatu perusahaan atau badan usaha. Sehingga dapat diketahui perkembangan kondisi operasional perusahaan. Berdasarkan Standard Akuntansi Keuangan (SAK) nomor 1 tahun 2009 menyatakan bahwa tujuan laporan keuangan adalah memberikan informasi mengenai posisi keuangan, kinerja keuangan,dan arus kas entitas yang bermanfaat bagi sebagian besar kalangan pengguna laporan dalam pembuatan keputusan ekonomi. Laporan keuangan juga menunjukkan hasil pertanggung jawaban manajemen atas sumber daya yang dipercayakan kepadanya, dalam rangka mencapai tujuan tersebut, laporan keuangan dipertimbangkan sebagai salah satu tanggung jawab pihak manajemen dengan pihak terkait dalam mengelola aset dalam periode tertentu.

Laba dapat menjadi pengukuran atas efisiensi serta dapat menjadi pengukur keberhasilan dan sebagai pedoman pengambilan keputusan manajemen dimasa yang akan datang. Penilaian atas laba juga merupakan tingkat pengembalian investasi (return), semakin besar laba yang diperoleh perusahaan, maka semakin baik dimata investor pada pasar modal. Bagian lain yang sering digunakan investor adalah informasi arus kas perusahaan. (Utomo, 2011). 
Arus kas dari aktivitas operasi diperoleh dari aktivitas penghasil utama pendapatan perusahaan. Arus kas dari aktivitas operasi merupakan indikator yang menentukan apakah aktivitas operasi perusahaan dapat menghasilkan arus kas yang cukup untuk melunasi pinjaman, memelihara kemampuan operasi perusahaan, membayar dividen, dan melakukan investasi baru tanpa mengandalkan sumber pendanaan dari luar. Komponen arus kas operasi ini yang dapat digunakan untuk menilai peluang investasi. Jika kas bersih yang disediakan oleh aktivitas investasi tinggi, berarti perusahaan mampu menghasilkan kas yang mencukupi secara internal dari operasi untuk membayar kewajibannya tanpa harus meminjam dari luar. Sebaliknya, jika jumlah kas bersih yang dihasilkan oleh aktivitas operasi rendah atau negatif, berarti perusahaan tidak mampu menghasilkan kas yang memadai secara internal dari operasinya.

Beberapa peneliti membuktikan bahwa adanya pengaruh positif dan negatif antara laba dan arus kas operasi terhadap return saham. Menurut Gilbert Ayub Tumbel, Jantje Tinangon dan Stanley Kho Walandouw (2017) menyatakan bahwa laba akuntansi berpengaruh positif dan signifikan tehadap return saham sedangkan arus kas operasi tidak berpengaruh signifikan terhadap return saham. Sementara hasil penelitian Putra dan Widyaningsih (2016) dan Anjani (2016) mengatakan bahwa arus kas operasi berpengaruh signifikan dan Anjani (2016) menyatakan bahwa laba tidak berpengaruh signifikan. Sedangkan penelitian yang dilakukan Probo Hutomo (2013) menyatakan bahwa laba akuntansi tidak berpengaruh signifikan tehadap return saham, sama hal nya dengan arus kas operasi juga tidak berpengaruh signifikan terhadap return saham.

Hasil penelitian-penelitian yang berbeda tersebut menimbulkan kesenjangan penelitian atau hasil yang tidak konsisten sehingga membutuhkan penelitian lebih lanjut. Hal ini yang membuat peneliti tertarik untuk melakukan pengujian kembali dengan judul penelitian "Analisis Pengaruh Laba Akuntansi dan Arus Kas Operasi Terhadap Return Saham ( Studi Pada Perusahaan Manufaktur Sektor Aneka Industri Yang Terdaftar Di Bursa Efek Indonesia Periode 2013-2017)".

\section{Perumusan Masalah}

Berdasarkan latar belakang diatas maka dapat dirumuskan masalah-masalah penelitian sebagai berikut :

1. Apakah laba akuntansi berpengaruh secara parsial terhadap return saham pada perusahaan manufaktur sektor aneka industri yang terdaftar di BEI periode 2013-2017?

2. Apakah arus kas operasi berpengaruh secara parsial terhadap return saham pada perusahaan manufaktur sektor aneka industri yang terdaftar di BEI periode 2013-2017?

3. Apakah laba akuntansi dan arus kas operasi berpengaruh secara simultan terhadap return saham pada perusahaan manufaktur sektor aneka industri yang terdaftar di BEI periode 2013-2017?

\section{Tujuan penelitian}

Tujuan penelitian ini adalah sebagai berikut :

1. Untuk mengetahui pengaruh laba akuntansi terhadap return saham pada perusahaan manufaktur sektor aneka industri yang terdaftar di BEI periode 2013-2017

2. Untuk mengetahui pengaruh arus kas operasi terhadap return saham pada perusahaan manufaktur sektor aneka industri yang terdaftar di BEI periode 2013-2017

3. Untuk mengetahui pengaruh laba akuntansi dan arus kas operasi secara bersama-sama terhadap return saham pada perusahaan manufaktur sektor aneka industri yang terdaftar di BEI periode 2013-2017 


\section{Manfaat Penelitian}

1. Bagi akademisi, menjadi bahan literatur untuk pengembangan penelitian selanjutnya tentang return saham.

2. Bagi peneliti, dapat memberikan kontribusi keilmuan dan mengembangkan wawasan dibidang akuntansi keuangan mengenai pengaruh laba akuntansi dan arus kas operasi terhadap return saham.

\section{LANDASAN TEORI}

\section{Laba Akuntansi}

Tujuan utama perusahaan adalah memaksimalkan laba. Pengertian laba secara operasional merupakan perbedaan antara pendapatan yang direalisasi yang timbul dari transaksi selama satu periode dengan biaya yang berkaitan dengan pendapatan tersebut (Zaki Muhammad, 2017). Pengertian laba menurut Harahap (2011:309) adalah perbedaan antara revenue yang direalisasi yang timbul dari transaksi pada periode tertentu dihadapkan dengan biaya-biaya yang dikeluarkan pada periode tersebut. Sementara pengertian laba yang dianut oleh struktur akuntansi sekarang ini adalah selisih pengukuran pendapatan dan biaya. Besar kecilnya laba sebagai pengukur kenaikan sangat bergantung pada ketepatan pengukuran pendapatan biaya. Laba mengandung lima sifat, yaitu :

1. Laba akuntansi didasarkan pada transaksi yang benar-benar terjadi, yaitu timbulnya hasil dan biaya untuk mendapatkan hasil tersebut.

2. Laba akuntansi didasarkan pada postulat periodik laba itu, artinya merupakan prestasi perusahaan itu pada periode tertentu.

3. Laba akuntansi didasarkan pada prinsip revenue yang memerlukan batasan tersebdiri tentang apa yang termasuk hasil.

4. Laba akuntansi memerlukan perhitungan terhadap biaya dalam bentuk biaya historis yang dikeluarkan perusahaan untuk mendapatkan hasil tertentu.

5. Laba akuntansi didasarkan pada prinsip macthing, artinya hasil dikurangi biaya yang diterima/dikeluarkan dalam periode yang sama.

\section{Konsep Laba}

Menurut Harahap (2011:310) menyebutkan beberapa kebaikan dari konsep laba akuntansi adalah sebagai berikut :

1. Dapat terus menerus ditelurusi dan diuji.

2. Karena perhitungannya didasarkan pada kenyataan yang terjadi (fakta) dan dilaporkan secara objektif, perhitungan laba ini dapat diperiksa (verifiability).

3. Memenuhi konsep conservatisme, karena yang diakui hanya laba yang direalisasi dan tidak memerhatikan perubahan nilai.

4. Dapat dijadikan sebagai alat kontrol oleh manajemen dalam melakukan fungsi-fungsi manajemen. 
Tabel

Konsep Laba, Perhitungan dan Penerima

\begin{tabular}{|l|l|l|}
\hline \multicolumn{1}{|c|}{ Konsep Laba } & \multicolumn{1}{|c|}{ Perhitungan Laba } & Penerima Informasi \\
\hline $\begin{array}{l}\text { Value added } \\
\text { (tambahan } \\
\text { nilai) }\end{array}$ & $\begin{array}{l}\text { Harga jual produksi dan jasa } \\
\text { perusahaan dikurangi harga pokok } \\
\text { barang dan jasa yang dijual }\end{array}$ & $\begin{array}{l}\text { Pegawai, pemilik, } \\
\text { kreditor dan pemerintah }\end{array}$ \\
\hline $\begin{array}{l}\text { Laba bersih } \\
\text { perusahaan } \\
\text { (Enterprise net } \\
\text { income) }\end{array}$ & $\begin{array}{l}\text { kelebihan hasil (revenue) dari } \\
\text { biaya, seluruh pendapatan(gain) } \\
\text { dan rugi. Biaya tidak termasuk } \\
\text { bunga, pajak dan bagi hasil }\end{array}$ & $\begin{array}{l}\text { Pemegang saham, } \\
\text { pemegang obligasi, dan } \\
\text { pemerintah }\end{array}$ \\
\hline $\begin{array}{l}\text { Laba bersih } \\
\text { bagi investor }\end{array}$ & $\begin{array}{l}\text { sama seperti enterprise income, } \\
\text { tetapi setelah dikurangi pajak } \\
\text { penghasilan }\end{array}$ & $\begin{array}{l}\text { Pemegang saham, } \\
\text { pemegang obligasi, dan } \\
\text { kreditor jangka panjang }\end{array}$ \\
\hline $\begin{array}{l}\text { Laba bersih } \\
\text { bagi pemegang } \\
\text { saham residual } \\
\text { (residual equity } \\
\text { holders) }\end{array}$ & $\begin{array}{l}\text { laba bersih kepada pemegang } \\
\text { saham dikurangi dividen saham } \\
\text { preferen }\end{array}$ & pemegang saham biasa \\
\hline
\end{tabular}

\section{Arus Kas}

Menurut pernyataan Standar Akuntansi Keuangan nomor 2 Tahun 2009, arus kas adalah arus masuk dan arus keluar kas dan setara kas (Ikatan Akuntansi Indonesia, 2013). Pengertian arus kas masuk dan arus kas keluar adalah aliran masuk (cash inflow) merupakan sumbersumber dariana kas diperoleh sedangkan arus kas keluar (cash outflow) merupakan kebutuhan kas untuk pembayaran-pembayaran (Martono dan Harjito, 2012)

Arus Kas masuk (cash inflow) dan arus kas keluar (cash outflow) masing-masing terbagi menjadi dua bagian, antara lain :

1. Arus Kas masuk (cash inflow)

a. Bersifat rutin, misalnya : penerimaan dari hasil penjualan secara tunai, penerimaan piutang yang telah dijadwalkan sesuai dengan penjualan kredit yang dilakukan, dan lain-lain.

b. Bersifat tidak rutin, misalnya : penerimaan uang sewa gedung, penerimaan moda saham, penerimaan utang atu kredit, penerimaan bunga dan lain-lain.

2. Arus kas keluar (cash outflow)

a. Bersifat rutin, misalnya: pembelian bahan baku dan bahan pembantu, membayar upah dan gaji, membeli peraatan kantor habis pakai, dan lain-lain.

b. Bersifat tidak rutin, misalnya: pembelian aset, pembayaran angsuran utang, pembayaran dividen, dan lain-lain.

Dari definisi diatas, maka arus kas merupakan jumlah kas yang mengalir masuk dan keluar pada periode tertentu.

\section{Arus Kas Operasi}

Menurut Pernyataan Standar Akuntansi Keuangan (PSAK) Nomor 2 Tahun 2009 mendefinisikan arus kas dari aktivitas operasi diperoleh dari aktivitas penghasil utama pendapatan perusahaan. Oleh karena itu, arus kas tersebut pada umumnya berasal dari 
transaksi dan peristiwa lain yang mempengaruhi penetapan laba atau rugi. Beberapa arus kas dari aktivitas operasi menurut PSAK No. 2 Tahun 2009 antara lain:

1. Penerimaan kas dari penjualan barang dan jasa.

2. Penerimaan kas dari royalty, fee, komisi dan pendapatan lain.

3. Pembayaran kas kepada pemasok barang dan jasa.

4. Pembayaran kas kepada karyawan.

5. Penerimaan dan pembayaran kas oleh perusahaan asuransi sehubungan dengan premi, klaim, anuitas, dan manfaat asuransi lainnya.

6. Pembayaran kas atau penerimaan kembali (restitusi) pajak penghasilan kecuali jika dapat diidentifikasi secara khusus sebagai bagian dari aktivitas pendanaan dan investasi.

7. Penerimaan dan pembayaran kas dari kontak yang diadakan untuk tujuan transaksi usaha dan perdagangan.

Jumlah arus kas yang berasal dari aktivitas operasi merupakan indikator yang menentukan apakah operasi perusahaan dapat menghasilkan arus kas yang cukup untuk melunasi pinjaman, memelihara kemampuan operasi perusahaan, membayar deviden dan melakukan investasi baru tanpa mengandalkan sumber pendanaan dari luar (Ikatan Akuntansi Indonesia, 2013).

Penyajian laporan arus kas menurut PSAK No. 2 Tahun 2009, entitas melaporkan arus kas dari aktivitas operasi dengan menggunakan salah satu dari dua metode berikut:

1. Metode langsung yaitu, dengan metode ini kelompok utama dari penerimaan kas bruto diungkapkan.

2. Metode tidak langsung yaitu, dengan metode ini laba atau rugi neto disesuaikan dengan mengoreksi pengaruh dari transaksi non kas, penangguhan atau akrual dari penerimaan pembayaran kas untuk operasi di masa lalu dan masa depan dan unsure penghasilan.

\section{Return Saham}

Legiman (2015) berpendapat bahwa return saham merupakan hasil yang diperoleh dari investasi. Harapan untuk memperoleh return juga terjadi dalam asset financial. Asset financial menunjukkan kesediaan investor menyediakan sejumlah dana pada saat ini untuk memperoleh sebuah aliran dana pada masa yang akan datang sebagai kompensasi atas faktor waktu selama dana ditanamkan dan risiko yang ditanggung. Dengan demikian para investor sedang mempertaruhkan suatu nilai sekarang untuk sebuah nilai yang diharapkan pada masa mendatang. Dalam konteks manajemen investasi, return atau tingkat keuntungan merupakan imbalan yang diperoleh dari investasi.

\section{Jenis-Jenis Return Saham}

Menurut Jogiyanto Hartono ada dua jenis return yaitu: "Return realisasi (realized return) merupakan return yang telah terjadi. Return ini dihitung dengan menggunakan data historis. Return realisasi penting karena digunakan sebagai salah satu pengukur kinerja perusahaan. Return realisasi juga berguna dalam penentuan return ekspektasi (expected return) dan risiko yang akan datang."

"Return ekspektasi (expected return) adalah return yang diharapkan akan diperoleh oleh para investor di masa yang akan datang". Dari teori definisi di atas dapat diambil kesimpulan bahwa jenis return terdiri dari:

\section{Realisasi}

Return realisasi merupakan return yang telah terjadi, dan penghitungannya menggunakan data histori perusahaan yang berguna untuk mengukur kinerja perusahaan. 
Return realisasi atau disebut juga return historis berguna juga untuk menentukan return ekspektasi (expected return) dan risiko di masa yang akan datang.

Beberapa pengukuran return realisasian yang banyak digunakan adalah return total (total return), relatif return (return relative), kumulatif return (return cumulative) dan return yang disesuaikan (adjusted return). Sedang rata-rata dari return dapat dihitung berdasarkan rata-rata aritmatika (arithmetic mean) dan ratarata geometric (geometric mean). Rata-rata geometrik banyak digunakan untuk menghitung rata-rata return beberapa periode, misalnya untuk menghitung return mingguan atau return bulanan yang dihitung berdasarkan rata-rata geometrik dari return-return harian. Untuk perhitungan retur seperti ini, rata-rata geometrik lebih tepat digunakan dibandingkan jika digunakn metode rata-rata aritmatika biasa.

\section{Ekpektasi}

Return ini digunakan untuk pengambilan keputusan investasi. Return ini lebih penting dibandingkan return historis (realisasi) karena return ini yang diharapkan oleh semua investor di masa yang akan datang.

Return ekspetasian (expected return) dapat dihitung berdasarkan beberapa cara sebagai berikut ini:

a. Berdasarkan nilai ekspetasian masa depan.

b. Berdasarkan nilai-nilai return historis.

c. Berdasarkan model return ekspetasian yang ada.

Secara sistematis, perhitungan return saham menurut Jogiyanto (2009:201) adalah sebagai berikut:

$$
\mathbf{R t}=\mathbf{P t}-\mathbf{P t}-\mathbf{1}
$$

Ket:

Rt $=$ Return saham periode ke-t

$\mathrm{Pt}=$ Harga saham periode pengamatan

Pt-1 = Harga saham periode sebelum pengamatan

Berdasarkan uraian di atas, maka return saham adalah pengembalian saham beserta hasilnya dari pihak broker atau perusahaan kepada investor yang telah melakukan investasi pada perusahaan tersebut.

\section{Hubungan Laba Akuntansi Terhadap Return Saham}

Perusahaan yang memiliki kemampuan untuk meningkatkan laba, cenderung harga sahamnya juga akan meningkat. Maksudnya jika perusahaan memperoleh laba yang semakin besar, maka secara teoritis perusahaan akan mampu membagikan deviden yang semakin besar dan akan berpengaruh secara positif terhadap return saham (Zaki Muhammad, 2017). Laba Akuntansi terus meningkat dapat memberikan sinyal positif kepada investor mengenai prospek dan kinerja perusahaan di masa depan, sehingga investor mau membeli saham tersebut. Adanya aksi beli ini dapat meningkatkan harga saham yang pada akhirnya meningkatkan return saham.

Hubungan laba akuntansi dengan return saham dapat dijelaskan melalui hasil penelitian Gilbert Ayub Tumbel, Jantje Tinangon dan Stanley Kho Walandouw (2017) yang menunjukan adanya hubungan antara laba akuntansi terhadap return saham. Dari hasil penelitiannnya disimpulkan bahwa laba akuntansi berpengaruh positif dan signifikan terhadap return saham. Dengan semakin tingginya laba akuntansi maka semakin naik return saham. Perusahaan yang menghasilkan laba semakin besar maka secara teoritis perusahaan itu akan mampu membagikan dividen yang semakin besar. Dengan meningkatnya dividen 
yang diterima oleh pemegang saham, maka return yang diterima oleh pemegang saham juga akan meningkat. Kondisi laba yang membaik akan berdampak nyata pada kinerja saham.

\section{Hubungan Arus Kas Terhadap Return Saham}

Aktivitas operasi adalah aktivitas penghasilan utama pendapatan perusahaan (principal revenue activities) dan aktivitas lain yang bukan merupakan aktivitas investasi dan pendanaan, umumnya berasal dari transaksi dan peristiwa lain yang mempengaruhi penerapan laba atau rugi bersih, dan merupakan indikator yang menentukan apakah dari operasi perusahaan dapat menghasilkan kas yang cukup untuk melunasi pinjaman, memelihara kemampuan operasi perusahaan, membayar deviden dan melakukan investasi baru tanpa mengandalkan pada sumber pendanaan dari luar. Sehingga adanya perubahan arus kas dari kegiatan operasi akan memberikan sinyal positif kepada investor, akibatnya investor akan membeli saham perusahaan tersebut yang pada akhirnya meningkatkan return saham (Zaki Muhammad, 2017).

Hubungan arus kas operasi dengan return saham dapat dijelaskan melalui hasil penelitian Fitria (2014) yang menunjukan adanya hubungan antara arus kas dari kegiatan operasi terhadap return saham. Dari hasil penelitiannnya disimpulkan bahwa arus kas operasi berpengaruh signifikan terhadap return saham. Makin tinggi arus kas dari aktivitas operasi maka semakin naik return saham. Kondisi arus kas perusahaan yang membaik maka dapat menjalankan bisnisnya dengan baik.

\section{METODE PENELITIAN}

\section{Populasi dan Sampel Penelitian}

Populasi dalam penelitian ini adalah seluruh perusahaan manufaktur yang terdaftar di Bursa Efek Indonesia selama periode tahun 2013-2017. Penarikan sampel yang akan dilakukan oleh peneliti adalah dengan menggunakan metode "purposive sampling". Dalam metode ini, pengambilan sampel berdasarkan suatu kriteria tertentu. Kriteria yang digunakan dapat berdasarkan pertimbangan (judgement) atau berdasarkan kuota tertentu (Erlina, 2011).

Pertimbangan yang dilakukan adalah sebagai berikut:

1. Perusahaan manufaktur yang terdaftar di Bursa Efek Indonesia (BEI) tahun 2013 - 2017.

2. Perusahaan yang dijadikan sampel memiliki kelengkapan data yang berkaitan dengan data sesuai model yang digunakan dalam penelitian ini.

\section{Jenis dan Pengumpulan Data}

Data yang digunakan merupakan data sekunder, yaitu data yang diperoleh secara tidak langsung melalui media perantara (diperoleh dan dicatat oleh pihak lain). Data tersebut diperoleh dari lembaga serta melalui studi pustaka yang ada hubungannya dengan masalah yang dibahas. Data pada penelitian ini merupakan data yang telah diolah dan diperoleh dari laporan keuangan tahunan perusahaan manufaktur yang terdaftar di Bursa Efek Indonesia periode 2013-2017, yakni laporan laba rugi dan arus kas melalui situs www.idx.co.id, serta data harga saham pada saat penutupan (closing price) melalui Indonesia Stock Exchange Factbook tahun 2013-2017.

\section{Variabel Penelitian}

1. Variabel dependen (Y)

Variabel terikat yang digunakan dalam penelitian ini adalah return saham.

2. Variabel independen (X)

Variabel bebas dalam penelitian ini adalah laba akuntansi (X1) dan arus kas operasi (X2) 


\section{Kerangka Pemikiran}

Berdasarkan teori yang telah diuraikan sebelumnya maka dapat disusun kerangka pemikiran sebagai berikut :

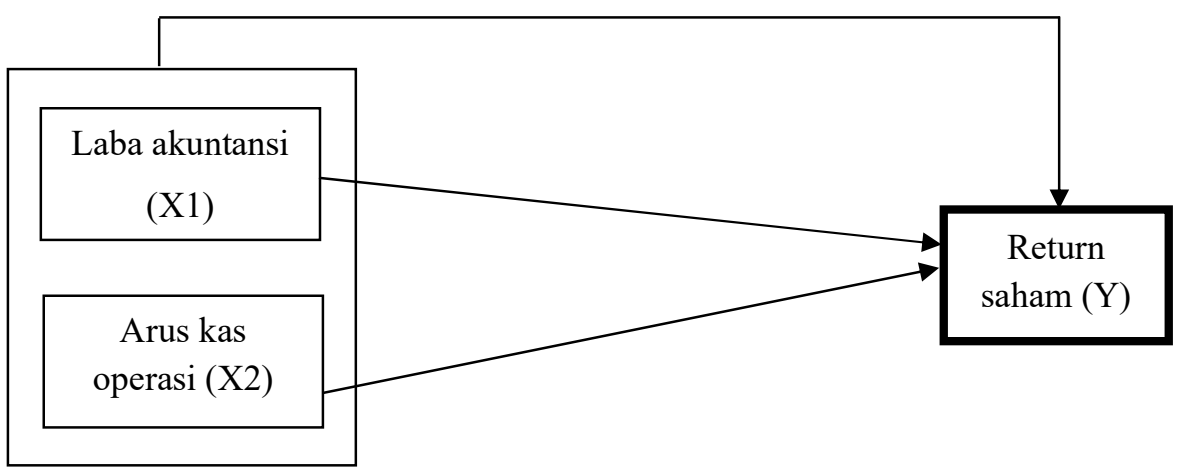

\section{Gambar \\ Kerangka Pemikiran}

\section{Hipotesis}

Ho1 : Laba akuntansi tidak berpengaruh secara signifikan terhadap return saham

Ha2 : Laba akuntansi berpengaruh secara signifikan terhadap return saham

Ho2 : Arus kas operasi tidak berpengaruh secara signifikan terhadap return saham

Ha2 : Arus kas operasi berpengaruh secara signifikan terhadap return saham

Ho3 : Laba akuntansi dan arus kas operasi secara simultan tidak berpengaruh signifikan terhadap return saham

Ha3 : Laba akuntansi dan arus kas operasi secara simultan berpengaruh signifikan terhadap return saham

\section{Metode Analisis Data}

Metode analisis data yang digunakan dalam penelitian ini adalah analisis deskriptif dan analisis statistik.

\section{Analisis Deskriptif}

Metode analisis deskriptif merupakan metode yang digunakan untuk menganalisis datadata yang tersedia dan diolah sehingga diperoleh gambaran yang jelas mengenai fakta-fakta fenomena yang diteliti. Analisis deskriptif ini bertujuan untuk memberikan penjelasan mengenai variabel yang digunakan dalam penelitian yang meliputi dependen (Y) yaitu return saham perusahaan manufaktur sektor aneka industri periode 2013-2017 dan variabel independen $(\mathrm{X})$ yang digunakan yaitu laba akuntansi dan arus kas operasi. 


\section{ANALISIS HASIL DAN PEMBAHASAN}

\section{Statistik Deskriptif}

\begin{tabular}{lr|r|r|r|r|r|} 
& \multicolumn{7}{c}{ Descriptive Statistics } \\
& N & Minimum & Maximum & \multicolumn{1}{c|}{ Sum } & Mean & Std. Deviation \\
\hline Laba_Akuntansi & 55 &,- 9755 & 19,6473 & 56,5132 & 1,027513 & 3,8536494 \\
\hline Arus_Kas_Operasi & 55 &,- 9865 & 30,6225 & 128,6003 & 2,338187 & 6,5290775 \\
\hline Return_Saham & 55 &,- 6448 & 1,5172 & 4,2770 &, 077764 &, 3017806 \\
\hline Valid N (listwise) & 55 & & & & & \\
\hline
\end{tabular}

\section{Uji Asumsi Klasik}

\section{Uji Normalitas}

Uji normalitas merupakan syarat mutlak sebuah data dapat dianalisis dan digunakan untuk mengetahui apakah model regresi dari nilai residual variabel terikat dan variabel bebas terdistribusi normal atau tidak. Model regresi yang baik adalah memiliki distribusi data normal dan mendekati normal.

Uji normalitas dalam penelitian ini adalah dilakukan dalam analisis statistik non-parametik uji Kolmogrov Smirnov. Data yang normal ditunjukkan dengan nilai uji Kolmogrov Smirnov yang memiliki nilai signifikansi diatas 0,05 . Selain uji non-parametik uji Kolmogrov Smirnov juga dapat dilihat dari penyebaran data (titik) normal P-Plot of Regression Standalized Residual (Probability Plot). Dasar pengambilan keputusan uji normalitas Plot (Probability Plot) adalah:

1. Data terdistribusi normal jika data atau titik menyebar disekitar garis diagonal dan mengikuti garis diagonal

2. Data tidak terdistribusi normal jika data atau titik menyebar jauh disekitar garis diagonal dan tidak mengikuti garis diagonal

Hasil uji Kolmogrov smirnov dapat dilihat pada tabel berikut ini :

Tabel

Uji Normalitas

One-Sample Kolmogorov-Smirnov Test

\begin{tabular}{llr} 
& & $\begin{array}{r}\text { Unstandardize } \\
\text { d Residual }\end{array}$ \\
\hline $\mathrm{N}$ & & 55 \\
\hline Normal Parameters & Mean &,- 7927 \\
\cline { 2 - 3 } & $\begin{array}{l}\text { Std. } \\
\text { Deviation }\end{array}$ &, 85185 \\
\hline Most Extreme & Absolute &, 217 \\
\cline { 2 - 3 } $\begin{array}{l}\text { Differences } \\
\text { Positive }\end{array}$ &, 143 \\
\cline { 2 - 3 } $\begin{array}{l}\text { Test Statistic } \\
\text { Asymp. Sig. (2-tailed) }\end{array}$ &,- 217 \\
\hline $\begin{array}{l}\text { a. Test distribution is Normal. } \\
\text { b. Calculated from data. } \\
\text { c. Lilliefors Significance Correction. } \\
\text { d. This is a lower bound of the true significance. }\end{array}$ \\
\hline
\end{tabular}


Hasil pengujian dengan menggunakan Uji Kolmogrov Smirnov memiliki nilai signifikansi diatas 0,05 yaitu sebesar 0,2 . Hasil pengujian menunjukkan bahwa data residual berdistribusi secara normal dan model regresi layak dipakai dalam penelitian ini. Untuk memperkuat hasil uji one sample kolmogrov smirnov ini maka juga dilakukan uji normalitas dengan grafik probability-plot sebagai berikut :

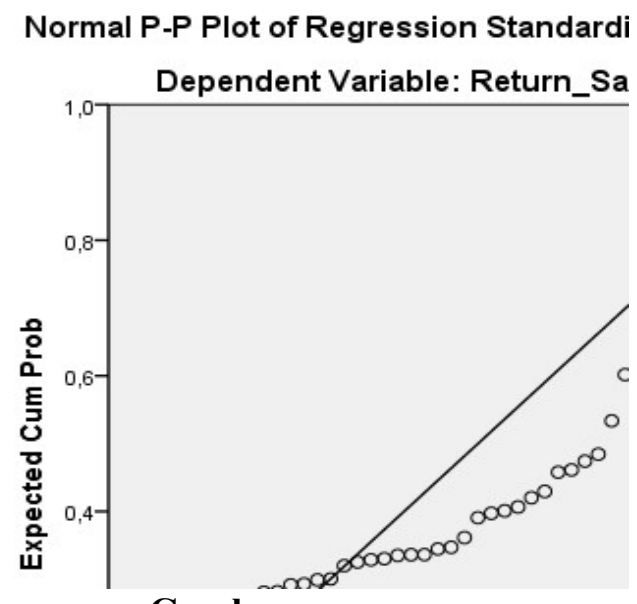

Gambar

\section{Normal P-P Plot Dependent Variabel : Return_Saham}

Berdasarkan gambar grafik normal P-Plot Return saham diatas, menjelaskan bahwa distribusi titik menyebar diagonal disekitar diagonal serta penyebaran mengikuti garis diagonal. Sehingga disimpulkan bahwa data dari populasi terdistribusi normal.

\section{Uji Multikolinearitas}

Uji Multikolinearitas bertujuan untuk menguji apakah adanya suatu hubungan linear yang sempurna (mendekati sempurna) antara beberapa variabel atau semua variabel bebas. Model regresi yang baik seharusnya tidak terjadi multikolinearitas. Dasar pengambilan keputusan uji multikolinearitas dapat dilakukan dengan melihat nilai tolerance dan VIF (Variance Inflation Faktors).

Jika nilai Tolerance $<0,10$ dan nilai VIF $>10$ maka terjadi gejala Multikolinearitas. Dan jika nilai Tolerance $>0,10$ dan VIF $<10$ maka tidak terjadi gejala multikolinearitas. Sedangkan VIF $=1 /$ tolerance, jika VIF $=10$ maka tolerance $=1 / 10=0,1$. Hasil Uji Multikolinearitas dalam penelitian ini dapat dilihat pada tabel berikut ini :

\section{Tabel}

\section{Uji Multikolinearitas}

Coefficients $^{\text {a }}$

\begin{tabular}{|c|c|c|}
\hline \multirow[b]{2}{*}{ Model } & \multicolumn{2}{|c|}{ Collinearity Statistics } \\
\hline & Tolerance & VIF \\
\hline (Constant) & & \\
\hline Laba_Akuntansi & 239 & 4,177 \\
\hline Arus_Kas_Operasi & 239 & 4,177 \\
\hline
\end{tabular}

a. Dependent Variable: Return_Saham 
Pada tabel diatas hasil pengujian multikolinearitas menunjukkan bahwa semua variabel bebas memiliki nilai tolerance $=0,239>0,1$ dan nilai VIF $=4,177<10$. Dengan demikian model regresi tersebut tidak memiliki masalah multikolinearitas.

\section{Uji Heteroskedastisitas}

Uji Heteroskedastisitas bertujuan untuk melihat nilai varians dari residual apakah sama atau heterogen. Pengujian Heteroskedastisitas pada penelitian ini menggunakan uji Glejser, adalah meregres nilai absolut residual terhadap variabel independen dengan persamaan regresi $\mathrm{Ut}=\alpha+\beta \mathrm{Xt}+\mathrm{vt}$ dan jika probabilitas signifikasi masing-masing variabel independen $>0,05$ maka dapat disimpulkan tidak terjadi heterokedastisitas (Ghozali,2013).

Heterokedastisitas juga dapat diketahui melalui Uji Scatterplot. Dasar pengambilan keputusan dengan analisis grafik Uji Scatterplot adalah jika ada pola seperti titik-titik yang ada membentuk pola tertentu yang teratur (bergelombang, melebar, kemudian menyempit), maka mengindikasikan telah terjadi Heteroskedastisitas sedangkan jika tidak ada pola yang jelas, serta titik-titik menyebar diatas dan dibawah angka 0 pada sumbu Y, maka tidak terjadi Heteroskedastisitas. Hasil pengujian Heteroskedastisitas menggunakan uji glejser dalam penelitian ini adalah sebagai berikut :

Tabel

Uji Heteroskedastisitas

\begin{tabular}{|c|c|c|c|c|c|c|}
\hline \multirow{3}{*}{\multicolumn{2}{|c|}{ Model }} & \multicolumn{3}{|c|}{ Coefficients $^{a}$} & \multirow[b]{3}{*}{$\mathrm{t}$} & \multirow[b]{3}{*}{ Sig. } \\
\hline & & \multicolumn{2}{|c|}{$\begin{array}{l}\text { Unstandardized } \\
\text { Coefficients }\end{array}$} & \multirow{2}{*}{$\begin{array}{c}\text { Standardized } \\
\text { Coefficients } \\
\text { Beta } \\
\end{array}$} & & \\
\hline & & $\mathrm{B}$ & Std. Error & & & \\
\hline 1 & (Constant) & , 154 & 038 & & 4,058 &, 000 \\
\hline & Laba_Akuntansi &,- 008 & ,009 &,- 117 &,- 847 & ,401 \\
\hline & $\begin{array}{l}\text { Arus_Kas_Operas } \\
\mathrm{i}\end{array}$ &,- 001 & ,002 &,- 048 &,- 346 & ,731 \\
\hline
\end{tabular}

a. Dependent Variable: Abs_Res

Berdasarkan output diatas, diperoleh nilai signifikan variabel laba akuntansi sebesar 0,401 lebih besar dari 0,05, artinya tidak terdapat heteroskedastisitas pada variabel laba akuntansi. Begitu juga dengan variabel arus kas operasi dengan nilai signifikan 0,731 lebih besar dari 0,05 yang artinya tidak terdapat heteroskedastisitas. Dengan demikian dapat disimpulkan bahwa tidak terjadi masalah heteroskedastisitas pada model regresi karena nilai signifikan (sig) kedua variabel $>0,05$.

Untuk memperkuat hasil pengujian Heteroskedastisitas menggunakan uji glejser, maka juga dilakukan uji scatterplot dalam penelitian ini adalah sebagai berikut : 


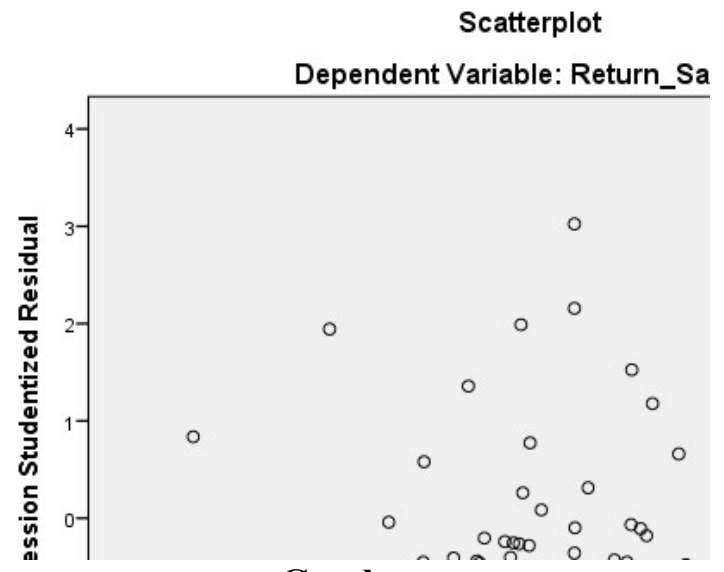

Gambar

Diagram Heteroskedastisitas

Hasil uji heteroskedastisitas pada gambar dapat terlihat titik-titik menyebar secara acak, menyebar diatas dan dibawah angka 0 pada sumbu $\mathrm{Y}$ dan tidak menunjukkan pola tertentu. Maka dapat disimpulkan model regresi tersebut tidak terjadi masalah heteroskedastisitas.

\section{Uji Autokorelasi}

Uji autokorelasi dalam penelitian ini dengan menggunakan uji Durblin Watson. Nilai Durbin Watson yang berada diantara nilai du dan 4-du menunjukkan model yang tidak terkena masalah autokorelasi. Hasil penelitian dengan menggunakan uji tersebut dapat dilihat pada tabel 5 sebagai berikut :

\section{Tabel}

Uji Autokorelasi

\section{Model Summary ${ }^{\mathrm{b}}$}

\begin{tabular}{lr|r|r|r|r} 
Model & R & R Square & $\begin{array}{c}\text { Adjusted R } \\
\text { Square }\end{array}$ & $\begin{array}{c}\text { Std. Error of } \\
\text { the Estimate }\end{array}$ & $\begin{array}{c}\text { Durbin- } \\
\text { Watson }\end{array}$ \\
\hline 1 &, $984^{\mathrm{a}}$ &, 968 &, 967 &, 0375582 & 2,275 \\
\hline
\end{tabular}

a. Predictors: (Constant), Arus_Kas_Operasi, Laba_Akuntansi

b. Dependent Variable: Return_Saham

Berdasarkan tabel diatas dapat diketahui bahwa nilai durbin watson adalah 2,275. Jika nilai durbin watson tersebut diantara du dan 4-du $(\mathrm{du}<\mathrm{d}<4$-du $)$ maka tidak terjadi masalah autokorelasi.

Tabel

Hasil Uji Autokorelasi dengan Durbin Watson (DW Test)

\begin{tabular}{|l|l|c|c|c|}
\hline $\begin{array}{l}\text { Autokorelasi } \\
\text { positf }\end{array}$ & $\begin{array}{l}\text { Daerah ragu- } \\
\text { ragu }\end{array}$ & $\begin{array}{l}\text { Tidak ada } \\
\text { autokorelasi }\end{array}$ & Daerah ragu-ragu & Autkorelasi negative \\
\hline \multicolumn{1}{c|}{$d l$} & $d u$ & $4-d u$ & $4-d l$ \\
& 1,32 & 1,466 & 2,534 & 2,68 \\
\hline
\end{tabular}

Nilai DW $=2,275$ 
Berdasarkan tabel diatas hasil uji autokorelasi dengan durbin watson diatas menunjukkan bahwa nilai durbin watson 2,275 berada diantara nilai du dan 4-du, maka dapat disimpulkan bahwa tidak terjadi masalah autokorelasi.

\section{Analisis Regresi Linier Berganda}

Analisis regresi berganda digunakan untuk menguji dua pengaruh atau lebih variabel independen terhadap variabel dependen. Analisis regresi berganda juga bertujuan untuk mengestimasi dan memprediksi nilai rata-rata variabel dependen berdasarkan nilai variabel independen yang diketahui. Analisis ini juga mengukur kekuatan hubungan atara dua variabel atau lebih dan menunjukkan hubungan antara variabel independen dengan variabel dependen.

\begin{tabular}{|c|c|c|c|c|c|c|c|c|}
\hline \multirow{3}{*}{\multicolumn{2}{|c|}{ Model }} & \multirow{2}{*}{\multicolumn{2}{|c|}{$\begin{array}{l}\text { Unstandardized } \\
\text { Coefficients }\end{array}$}} & $\begin{array}{l}\text { Tabel } \\
\text { alisis Regresi } \\
\text { efficients }{ }^{\text {a }}\end{array}$ & \multirow[b]{3}{*}{$\mathrm{t}$} & \multirow[b]{3}{*}{ Sig. } & \multirow{2}{*}{\multicolumn{2}{|c|}{$\begin{array}{l}\text { Collinearity } \\
\text { Statistics }\end{array}$}} \\
\hline & & & & \multirow[t]{2}{*}{$\begin{array}{l}\text { Standardize } \\
\mathrm{d} \\
\text { Coefficient } \\
\mathrm{s}\end{array}$} & & & & \\
\hline & & & $\begin{array}{l}\text { Std. } \\
\text { Error }\end{array}$ & & & & $\begin{array}{c}\text { Toleranc } \\
\mathrm{e}\end{array}$ & VIF \\
\hline 1 & (Constant) &,- 006 & ,005 & & $-1,071$ & ,289 & & \\
\hline & $\begin{array}{l}\text { Laba_Akuntan } \\
\text { si }\end{array}$ &, 023 & ,004 &, 321 & 6,365 &, 000 & ,239 & 4,177 \\
\hline & $\begin{array}{l}\text { Arus_Kas_Ope } \\
\text { rasi }\end{array}$ &, 022 & ,002 & 692 & 13,736 &, 000 & ,239 & 4,177 \\
\hline
\end{tabular}

a. Dependent Variable: Return_Saham

Berdasarkan hasil uji analisis diatas dapat diperoleh persamaan regresi linier berganda sebagai berikut :

Dimana :

Y : Return Saham

X1 : Laba Akuntansi

X2 : Arus Kas Operasi

e : error berikut :

Hasil persamaan regresi ini secara keseluruhan menunjukkan hasil intrepretasi sebagai

1. Nilai konstanta untuk persamaan regresi sebesar -,006 dengan nilai negatif dapat diartikan bahwa return saham akan bernilai -,006 apabila diasumsikan masing-masing variabel laba akuntansi dan arus kas operasi.

2. Koefisien regresi Laba Akuntansi $(\mathrm{X} 1)=0,23$ artinya setiap penambahan laba akuntasi sebesar 1\% jika variabel lainnya dianggap konstan, maka return saham akan mengalami pertambahan sebesar 0,23 kali. Koefisien bernilai positif artinya terjadi hubungan satu arah antara laba akuntansi dan return saham, semakin tinggi laba akuntansi maka semakin naik return saham (berpengaruh signifikan).

3. Koefisien regresi untuk arus kas operasi (X2) sebesar 0,22 artinya jika variabel lainnya tetap dan arus kas operasi mengalami kenaikan 1\% maka return saham akan 
mengalami pertambahan sebesar 0,22 kali. Koefisien bernilai positif artinya terjadi hubungan satu arah antara arus kas operasi dan return saham, semakin tinggi arus kas operasi maka semakin naik return saham ( berpengaruh signifikan).

\section{Uji Koefisien Determinasi}

Uji koefisien determinasi digunakan untuk mengukur seberapa jauh kemampuan variabel independen menerangkan variabel dependen. Pada penelitian ini hasil pengujian determinasi dapat dilihat ada tabel berikut :

\section{Tabel}

\section{Hasil Uji Koefisien Determinasi}

\begin{tabular}{|c|c|c|c|c|}
\hline \multicolumn{5}{|c|}{ Model Summary } \\
\hline Model & $\mathrm{R}$ & R Square & $\begin{array}{l}\text { Adjusted R } \\
\text { Square }\end{array}$ & $\begin{array}{l}\text { Std. Error of the } \\
\text { Estimate }\end{array}$ \\
\hline 1 & $984^{\mathrm{a}}$ & ,968 & 967 &, 0375582 \\
\hline
\end{tabular}

a. Predictors: (Constant), Arus_Kas_Operasi, Laba_Akuntansi

b. Dependent Variable: Return_Saham

Berdasarkan tabel diatas hasil uji koefisien determinasi model summary menunjukkan bahwa nilai koefisien determinasi Adjusted R square sebesar 0,967. Hal ini berarti bahwa seluruh variabel independen yaitu laporan akuntansi dan arus kas operasi yang mempengaruhi variabel dependent return saham adalah sebesar 96,7\% dan sisanya sebesar $3,3 \%$ dipengaruhi oleh variabel lain yang tidak diteliti dalam penelitian ini.

\section{Uji T}

Uji t ini merupakan pengujian variabel independen secara parsial terhadap variabel dependen. Tujuan dilakukan uji $\mathrm{t}$ adalah untuk mengetahui seberapa jauh pengaruh satu variabel independen yaitu laba akuntansi dan arus kas operasi secara individu terhadap variabel dependen yaitu return saham. Menentukan tingkat signifikan $(\alpha)$ yaitu sebesar $5 \%$ atau 0,05 dapat dilakukan dengan berdasarkan nilai probabilitas, dengan cara pengambilan keputusan adalah :

1. Jika nilai signifikansi penelitian $>0,05$ atau jika $\mathrm{T}_{\text {hitung }}<\mathrm{T}_{\text {table, }}$, maka Ho diterima dan Ha ditolak (tidak berpengaruh signifikan)

2. Jika nilai signifikansi penelitian $<0,05$ atau jika $\mathrm{T}_{\text {hitung }}>\mathrm{T}_{\text {tabel }}$ maka Ho ditolak dan Ha diterima (ada pengaruh signifikan)

Nilai t-tabel dihitung dari 2-tailed $\alpha=0,05 / 2=0,025$, df $=n-k-1$ ( $n$ adalah jumlah sampel dalam penelitian, $\mathrm{k}$ adalah jumlah variabel independen) maka nilai df pada penelitian ini adalah 55-2-1 $=52$. Sehingga diperoleh nilai t tabel $=2,007$

\section{Tabel}

\section{Hasil Uji T}

\section{Coefficients $^{\mathrm{a}}$}

\begin{tabular}{|c|c|c|c|c|c|c|}
\hline \multirow[b]{3}{*}{ Model } & & \multirow{2}{*}{\multicolumn{2}{|c|}{ Unstandardized Coefficients }} & \multirow{3}{*}{$\begin{array}{c}\text { Standardized } \\
\text { Coefficients } \\
\text { Beta }\end{array}$} & \multirow[b]{3}{*}{$\mathrm{t}$} & \multirow[b]{3}{*}{ Sig. } \\
\hline & & & & & & \\
\hline & & $\mathrm{B}$ & Std. Error & & & \\
\hline \multirow[t]{3}{*}{$\overline{1}$} & (Constant) &,- 006 & ,005 & & $-1,071$ & ,289 \\
\hline & Laba_Akuntansi &, 023 &, 004 & ,321 & 6,365 &, 000 \\
\hline & Arus Kas Operasi & 022 &, 002 & 692 & 13,736 &, 000 \\
\hline
\end{tabular}

a. Dependent Variable: Return_Saham 
Uji parsial pertama yang dilakukan adalah untuk mengetahui pengaruh laba akuntansi terhadap return saham, adapun hipotesis yang sudah ditetapkan peneliti adalah sebagai berikut :

Ho1 : Laba akuntansi tidak berpengaruh secara signifikan terhadap return saham

Ha1 : Laba akuntansi berpengaruh secara signifikan terhadap return saham

Uji parsial kedua yang dilakukan adalah untuk mengetahui pengaruh arus kas operasi terhadap return saham, adapun hipotesis yang sudah ditetapkan peneliti adalah sebagai berikut :

Ho2 :Arus kas operasi tidak berpengaruh secara signifikan terhadap return saham

Ha2 : Arus kas operasi berpengaruh secara signifikan terhadap return saham

Berdasarkan hasil yang diperoleh dari tabel diatas, maka hasil pengujian uji t dapat dijelaskan sebagai berikut :

1. Variabel laba akuntansi (X1) diperoleh nilai signifikansi 0,000 dan $t$ hitung yang diperoleh adalah 6,365. Maka nilai signifikansi $0,000<0,05$ dan nilai t hitung 6,365 $>$ 2,007. Maka dapat disimpulkan bahwa Ha diterima dan Ho ditolak. Dengan demikian hipotesis Hal diterima yaitu variabel laba akuntansi berpengaruh signifikan terhadap return saham pada perusahaan manufaktur sektor aneka industri yang terdaftar di Bursa Efek Indonesia.

2. Variabel arus kas operasi (X2) diperoleh nilai signifikansi 0,000 dan t hitung yang diperoleh adalah 13,736. Maka nilai signifikansi $0,000<0,05$ dan nilai t hitung 13,736> 2,007. Maka dapat disimpulkan bahwa Ha diterima dan Ho ditolak. Dengan demikian hipotesis $\mathrm{Ha} 2$ diterima yaitu variabel arus kas operasi berpengaruh signifikan terhadap return saham pada perusahaan manufaktur sektor aneka industri yang terdaftar di Bursa Efek Indonesia.

\section{Uji F}

Uji f bertujuan untuk mengetahui pengujian regresi secara keseluruhan variabel independen dengan variabel dependen secara bersama-sama dan untuk mengetahui tingkat signifikansi variabel independen terhadap variabel dependen secara besama-sama. Pengujian signifikansi persamaan regresi yang akan diperoleh dilakukan dengan melihat nilai $\mathrm{F}$ hitung pada uji F. Pengambilan keputusan uji F adalah sebagai berikut :

1. Jika $\mathrm{F}_{\text {hitung }}<\mathrm{F}_{\text {tabel, }}$ maka Ho diterima dan Ha ditolak

2. Jika $\mathrm{F}_{\text {hitung }}>\mathrm{F}_{\text {tabel, }}$ maka Ho ditolak dan Ha diterima

Dan melihat nilai signifikansi yaitu :

3. Jika nilai signifikansi $>0,05$ maka Ho diterima dan Ha ditolak

4. Jika nilai signifikansi $<0,05$ maka Ho ditolak dan Ha diterima

Dalam penelitian ini hasil uji $\mathrm{F}$ dapat dilihat pada tabel berikut:

\section{Tabel}

Hasil Uji F

ANOVA $^{\mathrm{a}}$

\begin{tabular}{|c|c|c|c|c|c|c|}
\hline Model & & Sum of Squares & df & Mean Square & $\mathrm{F}$ & Sig. \\
\hline \multirow[t]{3}{*}{1} & Regression & 2,249 & 2 & 1,124 & 797,075 &, $000^{\mathrm{b}}$ \\
\hline & Residual & ,073 & 52 & , 001 & & \\
\hline & Total & 2,322 & 54 & & & \\
\hline
\end{tabular}

a. Dependent Variable: Return_Saham

b. Predictors: (Constant), Arus_Kas_Operasi, Laba_Akuntansi 
Uji simultan F yang dilakukan adalah untuk mengetahui pengaruh secara bersama-sama variabel independen laba akuntansi dan arus kas operasi terhadap variabel dependen return saham, adapun hipotesis yang sudah ditetapkan peneliti adalah sebagai berikut:

Ho3 : Laba akuntansi dan arus kas operasi secara simultan tidak berpengaruh signifikan terhadap return saham

Ha3 : Laba akuntansi dan arus kas operasi secara simultan berpengaruh signifikan terhadap return saham

Berdasarkan tabel diatas Hasil Uji F maka pengambilan keputusan signifikan, interpretasi atas output ANOVA (uji F) adalah sebagai berikut :

1. F hitung yang didapat dari output sebesar 797,075 ( $\mathrm{df1}=\mathrm{k}$ dan $\mathrm{df} 2=\mathrm{n}-\mathrm{k} ; \mathrm{df} 1=2$ dan $\mathrm{df} 2=53$ ) dimana $\mathrm{k}$ adalah variabel independen sedangkan $\mathrm{n}$ adalah jumlah sampel penelitian. Sehingga diperoleh F tabel sebesar 3,17. Karena F hitung 797,075 > 3,17 maka dapat disimpulkan bahwa Ha diterima dan Ho ditolak.

2. Nilai signifikansi yang diperoleh sebesar $0,000<0,05$ maka dapat disimpulkan bahwa Ha diterima dan Ho ditolak.

Berdasarkan hasil tersebut maka dapat disimpulkan bahwa pengujian hipotesis $\mathrm{Ha} 3$ diterima, dimana kedua variabel independen yakni laba akuntansi dan arus kas operasi secara simultan berpengaruh signifikan terhadap variabel dependen yaitu return saham.

\section{Pembahasan}

\section{Pengaruh Laba Akuntansi Terhadap Return Saham}

Besarnya laba akuntansi diukur melalui selisih antara jumlah pendapatan perusahaan dikurangi dengan biaya operasional perusahaan. Berdasarkan hasil pengujian hipotesis yang dilakukan dari analisis tabel. Hasil Uji T, besarnya laba akuntansi diperoleh nilai t hitung $6,365>2,007$ dan nilai signifikan sebesar $0,00<0,05$ sehingga Ho ditolak dan Ha diterima, artinya bahwa variabel laba akuntansi berpengaruh signifikan terhadap return saham pada perusahaan manufaktur sektor aneka industri yang terdaftar di Bursa Efek Indonesia.

Hasil dari penelitian ini mendukung penelitian sebelumnya yang dilakukan oleh Gilbert Ayub Tumbel, Jantje Tinangon dan Stanley Kho Walandouw pada tahun 2017 yang menunjukan adanya hubungan antara laba akuntansi terhadap return saham. Dari hasil penelitiannnya disimpulkan bahwa laba akuntansi berpengaruh positif dan signifikan terhadap return saham karena laba atau keuntungan yang diperoleh dari kegiatan operasional perusahaan akan dibagikan kepada pemegang saham sebagai balas jasa telah menanamkan modalnya dalam perusahaan atau yang biasa disebut dengan dividen. Nantinya dividen tersebut merupakan salah satu komponen penyusun return saham selain capital gain. Perusahaan yang menghasilkan laba semakin besar, maka secara teoritis perusahaan itu akan mampu membagikan deviden yang semakin besar. Dengan meningkatnya dividen yang diterima oleh pemegang saham maka return yang diterima oleh pemegang saham juga akan meningkat. Kondisi laba akuntansi yang membaik berdampak nyata pada kinerja saham.

\section{Pengaruh Arus Kas Operasi Terhadap Return Saham}

Arus kas operasi adalah arus kas yang berasal dari aktivitas operasi terutama diperoleh dari aktivitas penghasil utama pendapatan perusahaan dan aktivitas lain yang bukan merupakan aktivitas investasi dan aktivitas pendanaan. Besarnya arus kas operasi diukur dari total arus kas masuk bersih dikurangi dengan total arus kas keluar. Berdasarkan hasil pengujian hipotesis yang dilakukan dari analisis tabel. Hasil Uji T, besarnya arus kas operasi diperoleh nilai signifikansi 0,000 dan $t$ hitung yang diperoleh adalah 13,736. Maka nilai 
signifikansi $0,000<0,05$ dan nilai t hitung 13,736 $>2,007$. Maka dapat disimpulkan bahwa Ha diterima dan Ho ditolak. artinya bahwa variabel arus kas operasi berpengaruh signifikan terhadap return saham pada perusahaan manufaktur sektor aneka industri yang terdaftar di Bursa Efek Indonesia.

Hasil penelitian ini sesuai dengan teori yang menyatakan bahwa semakin tinggi tingkat arus kas operasi maka akan menaikkan tingkat return saham, begitu pula sebaliknya semakin rendah arus kas operasi maka tingkat return saham juga akan berkurang. Penelitian ini juga mendukung penelitian yang dilakukan oleh Putra dan Widyaningsih (2016) yang berjudul Pengaruh Laba Akuntansi, Komponen Arus Kas dan Dividend Yield terhadap Return Saham, disimpulkan bahwa arus kas operasi berpengaruh signifikan terhadap return saham. Makin tinggi arus kas dari aktivitas operasi maka semakin naik return saham. Dengan demikian arus kas operasi dapat memberikan sinyal positif kepada investor mengenai prospek dan kinerja perusahaan di masa depan melalui aktivitas operasinya, sehingga investor tertarik membeli saham tersebut. Dengan adanya aktivitas tersebut menyebabkan harga saham mengalami kenaikan yang pada akhirnya meningkatkan return saham.

Di sisi lain, hasil penelitian ini bertolak belakang dengan penelitian yang dillakukan oleh Gilbert Ayub Tumbel, Jantje Tinangon dan Stanley Kho Walandouw pada tahun 2017. Mungkin dikarenakan dilakukan pada sampel perusahaan yang berbeda.

\section{Pengaruh Laba Akuntansi dan Arus Kas Operasi Terhadap Return Saham}

Berdasarkan tabel 10 hasil uji $\mathrm{F}$ diketahui nilai signifikansi laba akuntansi dan arus kas operasi adalah sebesar 0,00<0,05 dan nilai f hitung 797,075 $>3,17$ dari $\mathrm{f}$ tabel, maka Ha diterima dan Ho ditolak. Sehingga dapat disimpulkan bahwa laba akuntansi dan arus kas operasi secara simultan atau bersama-sama berpengaruh signifikan terhadap return saham pada perusahaan manufaktur sektor aneka industri yang terdaftar di Bursa Efek Indonesia.

Hasil penelitian ini sesuai dengan teori yang menyatakan bahwa semakin tinggi laba akuntansi dan arus kas operasi maka semakin tinggi pula tingkat return saham yang diperoleh. Penelitian ini juga mendukung penelitian yang dilakukan oleh Fitria pada tahun 2014, disimpulkan bahwa secara simultan arus kas dan pertumbuhan laba berpengaruh signifikan terhadap return saham. Kondisi arus kas dan laba perusahaan yang membaik maka dapat menjalankan bisnisnya dengan baik.

Disisi lain, penelitian ini tidak didukung oleh penelitian yang dilakukan oleh Gilbert Ayub Tumbel, Jantje Tinangon dan Stanley Kho Walandouw pada tahun 2017, karena pada penelitian sebelumnya hanya memfokuskan pengujian secara parsial (Uji T) antara laba akuntansi dan arus kas operasi terhadap return saham.

\section{KESIMPULAN DAN SARAN}

\section{Kesimpulan}

Teknik analisis data yang digunakan dalam penelitian ini adalah menggunakan teknik statistik deskriptif . Uji asumsi yang dilakukan dalam penelitian ini adalah uji asumsi klasik yang terdiri dari uji normalitas, uji multikolinearitas, uji heteroskedastisitas, dan uji autokorelasi. Pengujian hipotesis terdiri dari 6 hipotesis, dengan signifikansi tetapan 0,05. Dari hasil pengujian hipotesis, hipotesis yang diterima adalah $\mathrm{Ha} 1, \mathrm{Ha} 2$, dan $\mathrm{Ha} 3$. 
Berdasarkan hasil analisis data dan pembahasan yang telah diungkapkan, maka kesimpulan dari hasil penelitian yang berjudul analisis pengaruh laba akuntansi dan arus kas operasi terhadap return saham pada perusahaan manufaktur sektor aneka industri yang terdaftar di Bursa Efek Indonesia (BEI) periode tahun 2013 - 2017 adalah sebagai berikut :

1. Hasil pengujian hipotesis pertama, variabel laba akuntansi berpengaruh positif dan signifikan terhadap return saham (Ha1), yang dibuktikan oleh hasil pengujian hipotesis yang dilakukan dari analisis data tabel. Hasil Uji $\mathrm{T}$ dimana besarnya laba akuntansi diperoleh nilai t hitung 6,365 $>2,007$ dan nilai signifikan sebesar $0,00<0,05$ sehingga Ho ditolak dan Ha diterima, yang artinya bahwa semakin tinggi tingkat laba akuntansi dalam laporan laba rugi maka akan meningkatkan return saham. Hal ini mendukung bahwa pemakaian infomasi laba akuntansi sangat berpengaruh dalam pengambilan keputusan investasi kedepannya oleh investor jika laba akuntansi positif maka harga saham juga akan naik sehingga akan mempengaruhi return saham bagi investor yang menanamkan modalnya.

2. Hasil pengujian hipotesis kedua, variabel arus kas operasi berpengaruh positif dan signifikan terhadap return saham (Ha2), yang dibuktikan oleh hasil pengujian hipotesis yang dilakukan dari analisis data tabel. Hasil Uji T, dimana besarnya arus kas operasi diperoleh nilai signifikansi $0,000<0,05$ dan nilai t hitung 13,736 2,007. Maka dapat disimpulkan bahwa Ha diterima dan Ho ditolak, yang artinya bahwa semakin tinggi tingkat arus kas operasi maka akan menaikkan tingkat return saham. Dengan demikian arus kas operasi dapat memberikan sinyal positif kepada investor mengenai prospek dan kinerja perusahaan dimasa depan melalui aktivitas operasinya, sehingga investor tertarik membeli saham tersebut. Dengan adanya aktivitas tersebut menyebabkan harga saham mengalami kenaikan yang pada akhirnya akan meningkatkan return sahamnya. Hal ini dapat digunakan investor sebagai dasar pengambilan keputusan dalam memperoleh return saham.

3. Hasil pengujian hipotesis ketiga, variabel laba akuntansi dan arus kas operasi berpengaruh secara bersama-sama (simultan) terhadap return saham (Ha3), yang dibuktikan oleh hasil pengujian hipotesis yang dilakukan dari analisis data Tabel. Hasil Uji F, diketahui nilai signifikansi laba akuntansi dan arus kas operasi adalah sebesar 0,00 $<0,05$ dan nilai f hitung 797,075 $>3,17$ dari f tabel, maka Ha diterima dan Ho ditolak, yang artinya bahwa semakin tinggi tingkat laba akuntansi yang diiringi dengan meningkatnya arus kas operasi maka akan meningkatkan return saham. Hal tersebut membuktikan bahwa informasi laporan keuangan perusahaan digunakan investor dalam pengambilan keputusan investasi.

\section{Saran}

1. Bagi investor yang akan berinvestasi pada perusahaan manufaktur sektor aneka industri hendaknya lebih memperhatikan informasi mengenai laba akuntansi dan arus kas operasi, karena semakin besar laba dan arus kas operasi maka semakin tinggi pula return saham yang akan diperoleh.

2. Bagi investor dalam memprediksi return saham sebaiknya juga memperhatikan faktor dari luar lainnya yang dapat mempengaruhi harga saham sehingga diharapkan nantinya dapat berpengaruh juga terhadap return saham, seperti kondisi politik, sosial dan persaingan antara perusahaan manufaktur sektor aneka industri.

3. Bagi penelitian selanjutnya diharapkan dapat menambah variabel-variabel baru dan menambah sampel industri lainnya agar hasil yang diperoleh lebih baik dan bermanfaat serta kesalahan lebih sedikit. 


\section{DAFTAR PUSTAKA}

Anjani, Juwita Rini Dwi. 2016. Pengaruh Infomasi Arus Kas, Laba Kotor, Ukuran Perusahaan, Return On Asset (ROA) dan Debt Equity Ratio (DER) Terhadap Return Saham (Studi Empiris Pada Sektor Aneka Industri Yang Terdaftar di BEI Tahun 2012-2014). Universitas Muhammadiyah Surakarta. Surakarta.

DY Ilham Satria dan Sitti Hafasah. 2016. "Pengaruh laba akuntansi dan Komponen Arus Kas terhadap Harga Saham pada Industri Properti yang terdaftar di Bursa Efek Indonesia tahun 2010-2014”. Universitas Malikussaleh Lhokseumawe. Lhokseumawe.

Erlina. 2011. Metodologi Penelitian. Medan : USU Press.

Harahap, Sofyan Safri. 2011. Teori Akuntansi. Edisi Revisi 2011. Rajawali Pers. Jakarta

Hery. 2015. Analisis Laporan Keuangan Pendekatan Rasio Keuangan. CAPS. Yogyakarta.

Hutomo, Probo. 2013. "Pengaruh Arus Kas Operasi Dan Laba Akuntansi Terhadap Return Saham Pada Perusahaan Manufaktur Yang Terdaftar Di BEI”. Sekolah Tinggi Ilmu Ekonomi Perbanas. Surabaya.

Jogiyanto. 2010. Analisis dan Desain Sistem Informasi. Edisi IV. Andi Offset. Yogyakarta.

Kasmir. 2014. Bank Dan Lembaga Keuangan Lainnya. Rajawali Pers. Jakarta.

Legiman, Fachreza Muhammad, et al. 2015. Faktor-faktor yang mempengaruhi return saham pada perusahaan agroindustry yang terdaftar di Bursa Efek Indonesia periode 20092012. Jurnal EMBA, vol.3 No.3.

Muhammad, Zaki. 2017. "Analisis Pengaruh Arus Kas dan Pertumbuhan Laba Terhadap Return Saham Pada Perusahaan Manufaktur Sektor Industri Dasar dan Kimia Yang Terdaftar di BEI Tahun 2011-2014”. Universitas Lampung. Lampung.

Nuryaman \& Veronika Christina. 2015. Metodologi Penelitian Akuntansi. Ghalia Indonesia. Bogor.

Pramesti, Getut. 2017. Statistika Penelitian Dengan SPSS 24. Kompas Gramedia. Jakarta.

Putra, Yogie Rahmanda dan Widyaningsih, Mimin. 2016."Pengaruh Laba Akuntansi, Komponen Arus Kas, Dan Dividend Yield terhadap Return Saham (Studi Pada perusahaan Pertambangan Di Bursa Efek Indonesia (BEI)" Universitas Diponegoro Semarang. Semarang.

Sugiyono. 2003. Metode Penelitian Bisnis. Pusat Bahasa Depdiknas. Bandung.

Sunariyah. 2011. Pengantar Pengetahuan Pasar Modal. UPP STIM YKPN. Yogyakarta.

Tumbel, Gilbert Ayub, Jantje Tinangon dan Stanley Kho Walandouw. 2017."Pengaruh Laba Akuntansi dan Arus Kas Operasi Terhadap Return Saham Pada Perusahaan Manufaktur Sektor Industri Barang Konsumsi Yang Terdaftar Di Bursa Efek Indonesia )" Universitas Sam Ratulangi Manado. Manado.

Utomo, Seno Jodi.2011.”Analisis Pengaruh Arus Kas Operasi dan Laba Akuntansi Terhadap Return Saham Perusahaan Manufaktur Di Bursa Efek Indonesia" Universitas Negeri Semarang. Semarang.

www. IDX. co.id 